\title{
PENDIDIKAN KESEHATAN DENGAN MEDIA PUZZLE EFEKTIF MENINGKATKAN PERILAKU HAND HIGYENE PADA ANAK USIA SEKOLAH
}

\author{
Sinthia Rosanti Maelissa*, Romario Yakop Ukru \\ Program Studi Keperawatan, Universitas Kristen Indonesia Maluku, Jln Ot Pattimaipauw, \\ RT.003/RW.003, Talake, Kel Wainitu, Nusaniwe, Kota Ambon, Maluku, Indonesia, 97115 \\ *maelissasinthia@gmail.com (+6281235999400)
}

\begin{abstract}
ABSTRAK
Perilaku mencuci tangan pada Anak Usia Sekolah saat ini masih sangat rendah, sehingga berisiko terjadinya diare karena kuman yang dibawa menyebabkan pathogen baik secara langsung maupun tidak langsung. Sehingga dibutuhkan metode promosi yang tepat untuk meningkatkan pengetahuan tentang perilaku mencuci tangan yang tepat, salah satunya melalui metode permainan puzzle. Penelitian ini menggunakan desain pre-eksperimental dengan rancangan one-group pre-post test design yang bertujuan untuk mengidentifikasi pengaruh pendidikan kesehatan menggunakan media puzzle terhadap perilaku hand higyene pada anak usia sekolah di SD Kristen Waru Waipia. Populasi penelitian ini adalah seluruh siswa kelas 1 dan 2 di SD Kristen Waru Waipia dengan sampel berjumlah 31 responden yang akan diobservasi sebelum dan sesudah diberikan pendidikan kesehatan dengan media puzzle. Instrument dalam pengumpulan data berupa lembar observasi. Proses intervensi menggunakan protocol intervensi pendidikan kesehatan dengan media puzzle. Uji statistic yang digunakan yakni Wilcoxon. Hasil penelitian menunjukan sebelum mendapatkan pendidikan kesehatan dengan media puzzle hampir semua responden berjumlah 27 responden dari total 31 responden (95\%) tidak mampu mendemonstrasikan teknik 6 langkah Hand Higyene dengan baik dan benar, sedangkan setelah mendapatkan pendidikan kesehatan dengan media puzzle responden yang mampu mendemonstrasikan teknik 6 langkah Hand Higyene yang baik dan benar berjumlah 30 responden $(96.77 \%)$. Analisis pengaruh didapatkan $\mathrm{p}=0,000$ yang berarti ada pengaruh pendidikan kesehatan dengan media puzzle terhadap kemampuan Hand Higyene pada anak usia sekolah di SD Kristen Waru Waipia.
\end{abstract}

Kata kunci: anak usia sekolah; hand higyene; pendidikan kesehatan; media puzzle

\section{HEALTH EDUCATION WITH EFFECTIVE PUZZLE MEDIA ENHANCES HAND HIGYENE BEHAVIOR IN CHILDREN AGE SCHOOL}

\begin{abstract}
Hand washing behavior in School Age Children is still very low, so the risk of diarrhea is because the germs that are brought on cause pathogens both directly and indirectly. So we need the right promotional methods to increase knowledge about proper hand washing behavior, one of them is through the puzzle game method. This study used a pre-experimental design with a one-group pre-post test design aimed to identify the effect of health education using puzzle media on hand hygiene behavior in school-age children in Waru Waipia Christian Elementary School. The population of this study was all students of grade 1 and 2 at Waru Wiapia Christian Elementary School with a sample of 31 respondents who were observed before and after being given health education with puzzle media. Instrument in data collection in the form of observation sheet. The intervention process uses a health education intervention protocol with puzzle media. The statistical test used is Wilcoxon. The results showed that before getting health education with puzzle media, almost all respondents numbered 27 respondents from a total of
\end{abstract}


31 respondents (95\%) unable to demonstrate the 6-step Hand Higyene technique properly and correctly, whereas after getting health education with puzzle media respondents were able to demonstrate the technique The 6 steps of good and correct Hand Higyene are 30 respondents (96.77\%). Analysis of influence obtained $P=0,000$ which means there is an effect of health education with puzzle media on the ability of Hand Higyene in school-age children in Waru Waipia Christian Elementary School.

Keywords: health education; hand higyene; school age childre; puzzle games

\section{PENDAHULUAN}

Anak usia sekolah dikelompokan dalam usia rentan karena perilaku anak yang dapat mempengaruhi kesehatan khususnya selama berada di sekolah saat tidak bersama dengan orang tua seperti jajanan yang tidak sehat dan kebiasaan tidak mencuci tangan saat makan. Perilaku mencuci tangan yang tidak tepat dapat menjadi agen pembawa kuman yang dapat menyebabkan pathogen berpindah melalui kontak baik langsung maupun tidak langsung sehingga terjadinya Diare, (Kemenkes RI. 2018).

WHO (2017) mencatat bahwa mencuci tangan dengan benar dapat mengurangi angka kejadian diare, (Noviarni, 2016). Menurut data Riskesdas tahun 2018, perilaku mencuci tangan dengan benar di Indonesia hanya sebesar $47 \%$ dan Maluku secara khusus hanya sekitar $36 \%$, artinya masih ada sebagian besar masyarakat yang memiliki perilaku cuci tangan belum benar.

Perilaku mencuci tangan yang kurang pada anak usia sekolah disebabkan oleh pengetahuan yang masih rendah. Berbagai upaya untuk mensosialisasikan pentingnya mencuci tangan telah dilakukan selama ini, namun hanya dengan metode ceramah sehingga bagi anak usia sekolah dirasa kurang menarik. Pada Anak, diperlukan metode yang menarik dan tidak membosankan, salah satunya dengan metode bermain, (Notoadmodjo, 2015). Permainan yang dijadikan sebagai media pendidikan usia anak-anak harus dirancang dengan baik agar lebih menarik sebab anak-anak biasanya menyukai alat permainan dengan bentuk yang sederhana dan tidak rumit yang disertai dengan warna dan bentuk yang menarik yang salah satunya adalah media puzzle (Darmadi, 2017).

Puzzle merupakan salah satu media permainan anak yang menarik dan menyenangkan serta dapat meningkatkan kemampuan kogntif anak. Dengan menggunakan media puzzle kemampuan kognitif anak akan tercapai misalnya mengklasifikasikan benda berdasarkan warna atau bentuk atau ukuran, mengklasifikasikan benda ke dalam kelompok yang sama atau kelompok yang sejenis atau kelompok yang berpasangan dengan dua variasi dan kemampuan berpikir untuk memecahkan permasalahan yang sederhana.

Hikmawati (2016), membuktikan dalam penelitiannya bahwa ada pengaruh penyuluhan dengan media promosi puzzle gizi yang di berikan siswa meningkatkan pengetahuan, sikap dan tindakan siswa tentang gizi seimbang $(p=0.001<\alpha 0.05)$. Kasus diare secara umum di Provinsi Maluku pada tahun 2018 memperlihatkan bahwa jumlah kasus diare yang ditangani di Provinsi Maluku tahun 2018 sebanyak 2.385 $11.5 \%$ kasus dari 34.612 kasus yang ditargetkan. Di kota Ambon, penyakit diare maupun cacingan masih merupakan penyakit masyarakat yang 
sulit untuk dieliminasi. Untuk jumlah angka kesakitan di Ambon pada tahun 2015 yaitu 3.110 orang dengan kasus akibat infeksi cacing, dan 2.287 orang dengan kasus diare. Pada kasus tersebut, lebih banyak terjadi di kalangan anak-anak, terutama anak usia sekolah (Profil Kesehatan Kota Ambon, 2015).

Hasil observasi peneliti, perilaku hand hygiene pada siswa SD Kristen Waru masih sangat kurang, ditandai dengan perilaku siswa yang tidak mencuci tangan saat mengkosumsi jajanan. Siswa tidak memahami tentang teknik mencuci tangan dengan baik dan benar sehingga sangat berisiko terjadinya penyakit. Hasil wawancara yang dilakukan dengan Kepala Sekolah, didapatkan sebanyak 3 sampai 4 siswa yang harus absen karena mengalami diare. Namun tidak tahu apa penyebab sehingga siswanya mengalami diare. Sejauh ini Puskesmas dalam program UKGS yang dilakukan setiap bulannya memberi dampak bagi pengetahuan siswa karena hanya dengan metode ceramah tanpa melakukan simulasi ataupun menggunakan metode yang lebih menarik bagi siswa. Berdasarkan fenomena tersebut, maka perlu untuk melakukan penelitian tentang efektifitas metode puzzle untuk meningkatkan perilaku hand hygiene siswa di SD Kristen Waru Waipia.

\section{METODE}

Desain Penelitian ini adalah Quasi Eksperimen dengan pendekatan One group pre-post test design. Sampel dalam penelitian ini adalah siswa SD Kristen Waru Waipia kelas 1 dan 2 yang berjumah 31 orang yang dipilih dengan menggunakan teknik total sampling. Variable dalam penelitian ini adalah hand hygiene sebagai variable dependen dan permainan puzzle sebagai variable independen.

Instrument dalam penelitian ini menggunakan lembar observasi yang menggambarkan tingkat aktivitas permainan edukatif dan pengetahuan siswa/siswi dalam cara mempraktekkan cara Hand Higiene dengan baik dan benar. Observasi dilakukan dengan melakukan pengamatan dan pencatatan mengenai permainan edukatif dan cara mempraktekan Hand Hygiene dengan baik dan benar. Pada lembar observasi terdapat 6 item pertanyaan, yang diisi oleh peneliti dengan jawaban Ya dengan bobot skor 1 dan tidak dengan skor 1-6. Jadi total skor yang diperoleh terendah 1 dan tertinggi 6. Sedangkan pelaksanaan teknik hand hygiene diobservasi sebelum dan sesudah intervensi dilakukan. Setiap variabel dianalisis dengan menggunakan uji statistik paired-test, namun didapatkan data tidak berdistribusi normal sehingga dilanjutkan dengan uji wilcoxon signed rank test dengan tingkat kemaknaan 0,05

\section{HASIL}

Tabel 1, usia responden terbanyak berada pada usia 7 tahun, berjenis kelamin laki-laki. Tabel 2, hasil uji normalitas Shapiro wilk, didapatkan nilai signifikansi untuk tingkat keterampilan 6 Langkah Hand higyene pre test 0.000 dan tingkat keterampilan 6 Langkah Hand higyene Post test adalah 0.000. Dimana nilai signifikansi $\mathrm{p}<\alpha$ (0.05) sehingga dapat disimpulkan bahwa data tidak terdistribusi normal, maka uji statistic yang akan digunakan dalam penelitian ini adalah uji nonparametric test Wilcoxon. 
Tabel 1.

Karakteristik Responden $(n=31)$

\begin{tabular}{lcc}
\hline \multicolumn{1}{c}{ Karakteristik } & $\mathrm{f}$ & $\%$ \\
\hline Usia & & \\
6 & 8 & 25.8 \\
7 & 13 & 41.9 \\
8 & 10 & 32.3 \\
\hline Karakteristik & & \\
Laki-laki & 23 & 74.2 \\
Perempuan & 8 & 25.8 \\
\hline
\end{tabular}

Table 2.

Uji Normalitas Data

\begin{tabular}{|c|c|c|c|}
\hline Variable & Shapiro Wilk & $\mathrm{n}$ & Keterangan \\
\hline Keterampilan Hand Higyene Pretest & 0.000 & \multirow{2}{*}{31} & Tidak normal \\
\hline Keterampilan Hand Higyene Posttest & 0.000 & & Tidak normal \\
\hline
\end{tabular}

Tabel 3.

Hasil uji wilcoxon Sebelum dan Sesudah dilakukan pendidikan kesehatan menggunakan media puzzle terhadap perilaku hand higyene

\begin{tabular}{ccccccc}
\hline & $\mathrm{n}$ & Mean & $\mathrm{Sd}$ & $\mathrm{Z}$ & \multirow{2}{*}{$P$-value } \\
\cline { 1 - 4 } Keterampilan Hand Higyene Pretest & 31 & 3,06 & 0,442 & \multirow{2}{*}{-5156} & \multirow{2}{*}{0,000} \\
\cline { 1 - 2 } Keterampilan Hand Higyene Postest & 31 & 5,97 & 0,180 & & \\
\hline
\end{tabular}

Tabel 3, setelah dilakukan analisis menunjukkan bahwa nilai rata-rata keterampilan sebelum diberikan pendidikan kesehatan melalui media permainan edukatif puzzle adalah sebesar 3.06, sedangkan setelah diberikan pendidikan kesehatan melalui media permainan puzzle meningkat menjadi 5.97. Rata-rata keterampilan 6 langkah hand higyene pre-test dan post-test mengalami peningkatan sebesar 2,91 poin. Hal ini dapat disimpulkan bahwa terdapat peningkatan skor keterampilan hand higyene responden. Standar deviasi saat pre-test 0,442 dan setelah posttest menjadi 0,180 Hal tersebut menunjukan ada perbedaan yang signifikan antara keterampilan hand higyene sebelum dan sesudah diberikan pendidikan kesehatan menggunakan media puzzle.
Hasil analisa menggunakan uji wilcoxon didaptkan nilai $p=0,000$ ( $p<0,005)$ yang berarti bahwa ada pengaruh pendidikan kesehatan menggunakan media puzzle terhadap perilaku hand higyene pada anak usia sekolah di SD Kristen Waru Waipia.

\section{PEMBAHASAN}

Hasil uji Wilcoxon Test didapatkan nilai $p=0,000(\mathrm{p}<0.005)$ yang artinya $\mathrm{Ha}$ diterima dan $\mathrm{HO}$ ditolak dengan demikian ada Pengaruh Pendidikan Kesehatan Menggunakan Media Puzzle Terhadap Perilaku Hand Higyene Pada Anak Usia Sekolah Di SD Kristen Waru Waipia.

Penelitian ini media yang digunakan peneliti untuk memberikan pendidikan kesehatan adalah alat permainan edukasi (APE) puzzle. Intervensi puzzle yang diberikan merupakan gambaran 
ketrampilan tentang tekni 6 langkah Hand Higyene yang baik dan benar dengan tampilan gambar yang menarik.

Metode bermain puzzle adalah media permainan anak yang menarik dan menyenangkan akan merubah dan meningkatkan kemampuan untuk berperilaku sehat pada anak. Alat permainan untuk pendidikan usia anakanak harus dirancang dengan baik agar lebih menarik daripada permainan yang tidak didesain sebab anak-anak biasanya menyukai alat permainan dengan bentuk yang sederhana dan tidak rumit yang disertai dengan warna dan bentuk yang menarik yang salah satunya adalah media puzzle (Aisah dan Reza, 2014).

Diah \& Ery (2015) mengungkapkan bahwa ada pengaruh pemberian stimulus bermain Puzzle Terhadap Perkembangan Motorik Halus Anak Usia 4-6 Tahun Di Taman KanakKanak. Hal ini juga sejalan dengan Kartika (2016) yang mengungkapkan bahwa permainan puzzle juga dapat memberikan pengaruh terhadap peningkatan motorik halus pada anak prasekolah. Hal ini dapat diasumsikan bahwa bahwa permainan yang diberikan mampu dipahami dengan baik oleh responden sehingga terjadi peningkatan nilai dan rata-rata pengetahuan responden pada post-test. Dengan memilih media yang menarik, menjadikan media permainan puzzle yang dimainkan tidak membosankan, sehingga anak mampu memberikan perhatian yang baik.

\section{SIMPULAN}

Setelah diberikan intervensi permainan puzzlei, siswa mampu mendemonstrasikan teknik 6 langkah hand higyene dengan baik dan benar, sehingga ada pengaruh pendidikan kesehatan menggunakan media puzzle terhadap perilaku hand higyene pada anak usia sekolah di SD Kristen Waru Waipia.

\section{DAFTAR PUSTAKA}

Aisah, Nur \& Reza, Muhammad. (2014).Meningkatkan

Kemampuan Mencuci Tangan Melalui Metode Demonstrasi pada Kelompok $B$ di TK Unggulan Tepadu Al-Kautsar Mojokerto. E-JurnalUNESA, (Online), 3 (3):1-8, diaksespadatanggal2 Januari 2018

Barokah, A. Haryani, S. Syamsul. (2012). Pengaruh Terapi Bermain Puzzle Terhadap Perilaku Kooperatif Anak Usia prasekolah Selama Hospitalisasi Di RSUD Tugurejo Semarang.

Darmadi. (2017). Pengembangan Model dan Metode Pembelajaran dalam Dinamika Belajar Siswa. Yogyakarta: Deepublish-Grup Penerbitan CV. Budi Utama

Diah,. \& Ery. (2013). Pengaruh Pendidi-kan Kesehatan terhdap Perilaku Cuci Tangan Pakai Sabun pada Anak Usia Sekolah Di SD 2 Jambi-dan Banguntapan Bantul.

Hikmawaty Zainab, dkk. (2016) Pengaruh penyuluhan dengan media promosi Puzzle Gizi terhadap perilaku gizi seimbng pada siswa kelas 5 di SD Negeri 06 Posiakota Kendari.

Kartika, dkk. (2016). Jurnal Kesehatan Masyarakat (e-Journal) Volume 4, nomor 5, Oktober 2016 (ISNN: 2356-2246). Faktor-faktor yang Berhubungan dengan Perilaku Cuci Tangan Pakai Sabun pada 
Siswa Sekolah Dasar Negeri Sambiroto 01 Kota Semarang. Diakses tanggal 24 Juni 2018

Kementerian kesehatan RI. ( 2018). Hasil utama Riset kesehatan Dasar 2018.

Kurniawan,

Agung. (2017). International Conference On Special Education In Southeast Asia Region 7th Series 2017. Pengaruh Metode Demonstrasi Terhadap Kemampuan Mencuci Tangan Anak Tunagrahita Ringan 11 Kelas VII SMPLB. Diakses tanggal 3 Januari2018

Kuswoyo. (2013). Pengaruh Pendidikan Kesehatan Dengan Metode Bermain Puzzle Terhadap Sikap Anak Usia Sekolah (6-12) Tahun Tentang Penyakit ISPA di Kecamatan Ledokombo kabupaten Jember. Universitas MuhammdiyahJember.

Kusumaningtyas (2016) perkembangan kemampuan kognitif terjadi pada masa anak usia sekolah. Yogyakarta: Nuha Medika

Ningsih dan Isnaeni.(2015). Naskah Publikasi STIKes Aisyah Yogyakarta. Pengaaruh Pendidikan Kesehatan Mencuci Tangan pada Anak di SD Muhammadiyah Wirobrajan III. Diakses tanggal 24 Juni 2018
Noviarni, S. (2015). Cuci tangan pakai sabun tekan tingkat kematian. http://www.koran sindo.com/ diakses 10 november 2015 .

Nurjanah, I. (2012). Pengaruh Pendidikan Kesehatan dengan Metode Bermain Puzzle Terhadap Motivasi Pencegahan Penyakit Cacingan Pada Anak Usia Sekolah. Universitas Muhammdiyah Jember.

Notoatmodjo dalam Windasari, 2014, dalam Apilaya, 2016,

Proverawati dan Rachmawati. (2012). PHBS-Perilaku Hidup Bersih dan Sehat. Yogyakarta : Nuha Medika

Rahmawati dan Noviani. (2017). Pengaruh Pendidikan Kesehatan Terhadap Tingkat Pengetahuan Hand Hygiene pada Anak Sekolah Dasar di SD Muhammadiyah Senggotan. Diakses tanggal 23 Juni 2018 